\title{
Climate Change and Real Estate Prices
}

\author{
Igor Semenenko ${ }^{1} \&$ Junwook Yoo ${ }^{2}$ \\ ${ }^{1}$ Acadia University, Wolfville, Canada \\ ${ }^{2}$ California State University, East Bay Hayward, United States \\ Correspondence: Igor Semenenko, Acadia University, Wolfville, NS, B4P 2R6, Canada. Tel: 1-902-585-1294. \\ E-mail: igor.semenenko@acadiau.ca
}

Received: August 26, 2019

Accepted: September 15, 2019

Online Published: October 8, 2019

doi:10.5539/ijef.v11n11p1

URL: https://doi.org/10.5539/ijef.v11n11p1

\begin{abstract}
Direct real estate returns are correlated with shifts in weather patterns, which are proxied by changes in four moments of distribution for differences in average and maximum daily temperatures, deviations from optimal temperatures and climate risk index reported by Germanwatch. Changes in the volatility of daily temperatures are inversely correlated with direct real estate returns. The volatility effect appeared to be marginal in 1996-2007, but it became more pronounced in 2010-2017. Other moments of the distribution, including changes in means, skewness and kurtosis, fail to obtain predictive power. Results are robust to tests in a smaller sample of capital cities and the exclusion of observations with the most significant volatility increases.
\end{abstract}

Keywords: climate change, direct real estate, residential real estate, moments of distribution, volatility, temperature

\section{Introduction}

Increase in global average temperatures has been documented since the mid-twentieth century, and weather scientists agree that global surface temperatures will increase by 1.5-2.0 degrees Celsius between by the end of the $21^{\text {st }}$ century relative to 1986-2005, triggering heatwaves and changes in precipitations (IPCC, 2014).

Climate change affects economic outcomes directly and indirectly. First, it can impact the aggregate level of output, including labour productivity. Second, it can lower forward-looking asset prices by applying higher discount rates due to uncertainty and risk and/or by changing expected cash flows. The latter strand of literature includes explanations based both on market efficiency (Giglio, Maggiori, Stroebel, \& Weber, 2015) and ehavioural arguments (Hirshleifer \& Shumway, 2003).

Not surprisingly, forecasts of climate change on economic activity differ. Initially, weather impact research focused on the most vulnerable industries - health, insurance, tourism (Butsic, Hanak, \& Valletta, 2011; Dlugolecki, 2008) and construction (see Ballesteros-Perez, Smith, Lloyd-Papworth, \& Cooke, 2018, for excellent literature overview on the impact of climate change on construction). With a growing realization of climate change onset, the effort shifted from measuring weather impact to analysis of most vulnerable industries and areas of the globe (Patt et al., 2010; E. Somanathan, R. Somanathan, Sudarshan, \& Tewari, 2015; Zander, Botzen, Oppermann, Kjellstrom, \& Garnett, 2015). Finally, several studies attempted to performa broader assessment of climate risk impact on the aggregate economy (Deryugina \& Hsiang, 2014).

Roback's (1982) study was the first to study impact of climate on house prices. More recently, a growing body of research attempted to establish a link between real estate economics and climate change (Bunten \& Kahn, 2014; Giglio et al., 2015). In its methodological approach, this study follows previous work that utilized a regression framework to assess the effects of climate change on asset prices (Kahn, 2009; Hanak \& Valetta, 2011; Albouy et al., 2016). Our paper contributes to a growing body of research on climate adaptation policies (Lesnikowski et al., 2019; Mechler et al., 2019).

In the real estate space, our paper is directly related to studies on market efficiency and risk premiums (Linneman, 1986; Case \& Shiller, 1989; Ho, Addae-Dapaah, \& Glascock, 2015). Several authors, including Case and Shiller (2003), Krainer and Wei (2004) and Campbell, Davis, Gallin, and Martin (2009), related house price inflation to lower expected risk premiums, suggesting one possible link between real estate returns and proxies for climate changes. 
This paper attempts to estimate the potential impact of change in weather conditions on real estate prices using a sample of international data. We do not find a link between temperature increases and house inflation, but volatility changes in average daily temperatures are inversely related to price dynamics. These results suggest that the real estate market could be pricing in changes in long-term weather trends.

The rest of the article is structured as follows. The next section introduces my empirical methodology, which is followed by a description of the data, discussion of results, robustness checks, and concluding remarks. The appendix describes sources of data for weather and several control variables used in this study.

\section{Methodology}

\subsection{Motivation}

Ex-ante, it is not apparent that climate change will negatively affect asset prices, including direct real estate. Bunten and Kahn (2014) cite price increases in Miami, a coastal area at high risk of sea-level rise, suggesting that homeowners are not compensated for risk with a price discount. to other market segments, direct real estate is a prime candidate to test the impact of weather changes. First, it is a physical asset directly exposed to elements. Second, whereas corporations can diversify their asset base via cross-border investments and acquisitions, residential real estate is trapped by geography.

I put to the test several variables to examine their potential impact on housing prices. First, I $1^{\text {st }}, 2^{\text {nd }}$ and $4^{\text {th }}$ moments of the distribution on daily temperature changes over 1996-2017 period compared to a control sample of 1950-1990. Real estate price changes could react to both temperature changes and shift in the properties of the distribution - higher volatility and fatter tails. Further, climate change is primarily related to temperature increases, so we examine the change in statistical properties of both average and maximum daily temperatures. In existing literature, Li, Cheng, and Shoaib (2018) document impact of temperature on real estate prices in the Hong Kong market, and Li (2009) finds inverse relationship between volume of monthly residential properties transactions and various weather metrics in Hong Kong.

The motivation to examine higher moments of distribution is related to Nordhaus (2001), Weitzman (2011) and Barro (2006). Barro employs rare-disasters framework to explain high equity premiums, low real interest rates and volatile stock returns and suggests an extension of the asset menu to include real estate and related housing price to disaster probabilities. This is the proposition tested in this study using higher moments of distribution and climate risk index reported by Germanwatch (see discussion below).

Second, we investigate whether asset prices are related to temperature deviation from optimal levels. Two benchmarks were tested - a daily average of 65 degrees Fahrenheit (18.3 degrees Celsius), a preferential daily average of the U.S. households (Albouy et al., 2016) and 57.7 degrees Fahrenheit (14.3 degrees Celsius), the daily average temperature in San Francisco in 1950-1990. This avenue of investigation was motivated by Bunten and Kahn (2014), who postulated that real estate price differential between San Francisco and Detroit could narrow if the climate in New England improves.

Finally, we examine whether housing prices are related to the risk of extreme events using climate risk index (CRI) developed by Germanwatch e.V., which uses data from the Munich Re reinsurance company. The index takes on low values when the climate is consistently fraught with risks or if a country is temporarily affected by adverse weather events.

Methodologically it is difficult to untangle climate trends defined as longer-term shifts in the climate over several decades from climate shocks - extreme weather events like natural disasters, floods, and droughts which are exacerbated by climate trends. However, the use of different proxies can help capture some of the effects of climate changes on asset prices.

\subsection{Time Effects}

We divide our sample into three subperiods using two classification criteria. One is related to the incidence of climate change, and the other reflects the onset of the financial crisis. To measure how climate risk assessment has changed over the period included in this study, we examined how the number of publications on related topics has changed in media outlets. We conducted a search on "climate change" string in the Factiva database and determined that coverage increased dramatically in 2007 (see figure 1).

This finding, together with the timing of the most recent financial crisis, prompted sample separation into three subperiods, including 1996-2007, 2008-2009 and 2010-2017. We examine the impact of weather metrics on property prices in each of these subsamples. 


\subsection{Literature Review and Model Specifications}

Literature that examines the influence of macroeconomic variables on house prices could be grouped into three broad categories: econometric models, affordability indicators and asset pricing approach (Girouard, Kennedy, van den Noord, \& Andre, 2006; Kishor \& Marfatia, 2017). This study falls into the first of the three groups - it employs econometric models to establish fiscal policies impact on housing prices.

To the best of our knowledge, this the first study that relates climate change to a panel dataset of international residential real estate. One of the advantages of this paper is that it puts to test a variable that is clearly exogenous in the context of employed econometric models.

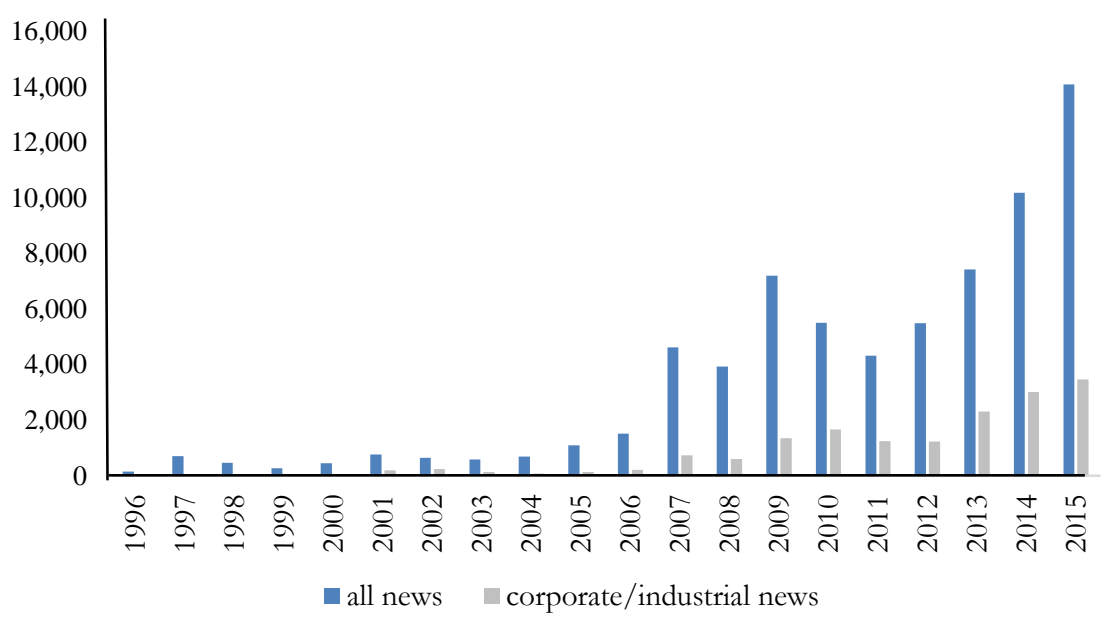

Figure 1. Number of hits on "climate change" in Factiva in "All News" and "Corporate/Industrial News" category

We use two model specifications to differentiate between long-term and transitory effects - short-run price reaction can differ from the long-run response (Adams \& Füss, 2010; Kishor \& Marfatia, 2017). First, we run an OLS regression with mean changes in inflation-adjusted real estate returns as a dependent variable, weather change proxies and a group of control variables:

$$
\overline{\mathrm{r}}=\alpha_{\mathrm{i}}+\beta_{\text {WEATHER }} ? \Delta_{\text {WEATHER }}+\beta_{\mathrm{t}} ? \mathrm{X}_{\mathrm{it}}+\mathrm{e}_{\mathrm{it}},
$$

where a mean inflation-adjusted return on real estate $\Delta_{\text {шЕАтнеR }}$ measures climate change impact and $\mathrm{X}_{\mathrm{ut}}$ is a vector of country characteristics. Second, I re-visit the results using a panel data set, annual frequency data and Newey-West corrected errors. We put weather change variable to test in six models. All OLS models with means - see tables 4, 6 and 8 - use the same specifications as reported in panel A in table 4, but due to space considerations, we report only betas on climate change proxies and goodness-of-fit statistics. In a similar vein, all annual regressions reported in tables 5 and 7 replicate models from panel A of table 5. In each table, weather change betas are reported for three subperiods.

Explanatory variables aim to capture demand- and supply-side factors. The determinants from the demand side include real interest rate, population and immigration increases, domestic currency depreciation, changes in household credit and real GDP per capita growth, while supply (cost) side is captured by a change in building permits and construction costs (see Appendix A for sources of data).

\section{Data}

Daily weather data were retrieved from the National Centers for Environmental Information of National Oceanic and Atmospheric Administration (see Appendix A for exact locations). Weather stations were chosen based on proximity to capital (major) cities; when data were incomplete, the second- and third-best options were chosen. When fewer than 360 observations were available for each year, that data was omitted from calculations. This filter reduced weather sample size by 8 percent in 1950-2017. Table 1 reports averages for three moments of distribution based on daily average and maximum temperatures, and changes in subsequent periods. 
Regression models test weather change variables in OLS models with means and Newey-West models using data with annual frequencies. To make results directly comparable, we restricted our sample to include countries for which data was available for all years in 2010-2017 period. This left 50 countries in the sample.

Table 1. Moments of distribution for weather variables in national markets

\begin{tabular}{ccccccc}
\hline & Mean & Volatility & Kurtosis & Mean of maximum & Volatility of maximum & Kurtosis of maximum \\
\hline $1951-1990$ & 13.1 & 6.64 & -0.63 & 17.3 & 7.49 & -0.59 \\
$1996-2007$ & 0.78 & -0.04 & 0.03 & 0.82 & -0.07 & 0.00 \\
$2008-2009$ & 1.08 & -0.19 & -0.04 & 1.28 & -0.22 & 0.00 \\
$2010-2017$ & 1.10 & 0.09 & -0.02 & 1.23 & -0.02 & 0.02 \\
\hline
\end{tabular}

Note. the table reports first, second and fourth moment of distribution for average and maximum daily temperatures for control period from 1951 to 1990 and changes in subsequent periods.

Data on GDP growth, population changes, net migration and foreign exchange rates were sourced from the World Bank and the International Monetary Fund for Taiwan. The World Bank reports net migration in five-year intervals, so each figure was spread over a five-year period and scaled by starting population level to measure annual change. Total credit to households was obtained from the Bank for International Settlements credit to the non-financial sector (CRE) dataset (Note 1). Appendix A reports sources for interest rates, building permits and construction cost series from the DataStream database system. Use of a 10-year Treasury bond yield as a measure of nominal long-term discount rate is consistent with Lai and Van Order (2017) and Campbell et al. (2009).

\section{Empirical Analysis}

\subsection{Weather Proxies and Correlations Analysis}

Table 2 reports pairwise correlations between inflation-adjusted returns and various climate change proxies. Increase in volatility is inversely related to housing inflation in 2010-2017 and, less significantly, in 1996-2007. Maximum temperatures convey less information than average daily temperatures. Finally, neither climate risk index nor changes in temperature deviations from optimal values were significant in 2010-2017. It appears that households valued temperature changes toward optimum in 1996-2007, but not in later periods. In the remainder of this article, our analysis will focus on changes in the second moment of distribution for daily average temperatures.

Table 2. Pairwise correlations

\begin{tabular}{|c|c|c|c|c|c|c|}
\hline & \multicolumn{3}{|c|}{ Variable means over each period } & \multicolumn{3}{|c|}{ Annual frequencies } \\
\hline & 2010-2017 & $2008-2009$ & 1996-2007 & 2010-2017 & 2008-2009 & 1996-2007 \\
\hline Mean & -0.20 & -0.05 & 0.24 & -0.02 & 0.10 & 0.08 \\
\hline Volatility & $-0.49 * * *$ & 0.15 & $-0.28^{*}$ & $-0.19 * * *$ & -0.00 & -0.07 \\
\hline Excess kurtosis & -0.12 & -0.08 & $0.39 * *$ & -0.04 & -0.06 & 0.02 \\
\hline Mean of maximum & -0.33 & 0.07 & $0.37 * *$ & -0.04 & 0.20 & $0.14 *$ \\
\hline Volatility of maximum & $-0.37^{*}$ & 0.16 & -0.31 & $-0.13^{*}$ & -0.09 & -0.10 \\
\hline Excess kurtosis of max. & -0.04 & 0.11 & 0.23 & -0.01 & 0.08 & 0.05 \\
\hline Climate risk index & 0.07 & -0.19 & 0.24 & 0.03 & -0.08 & $0.12 * *$ \\
\hline Deviation from 65 Fahr. & -0.02 & $0.25 *$ & $-0.45 * * *$ & -0.04 & 0.16 & $-0.21 * * *$ \\
\hline Deviation from California & 0.20 & $0.25 *$ & $-0.38 * *$ & 0.04 & 0.13 & $-0.16^{* * *}$ \\
\hline
\end{tabular}

Note. the table reports pairwise correlations of inflation-adjusted real estate returns and various weather change proxies - three moments of distribution for average and maximum daily temperatures, climate risk index and two measures of average temperature deviation from optimal temperatures defined as 65 Fahrenheit and San Francisco averages in 1950-1990.*** and *** indicate a p-value of 10\%, 5\%, and 1\%, respectively.

Table 3 reports 2010-2017 inflation-adjusted returns in 50 national markets included in this study, 28 capital cities and three moments of distribution that characterize weather changes relative to the 1950-1990 control period - change in mean annual temperature, the volatility of temperature and kurtosis, which measures fat tails of the distribution. 
Table 3. Changes in moments of distribution in 2010-2017 relative to 1950-1990 control period

\begin{tabular}{|c|c|c|c|c|c|c|}
\hline $\mathrm{N}$ & Country & Return in national market & Return in capital cities & Change in mean & Change in volatility & Change in kurtosis \\
\hline 1. & Spain & $-3.4 \%$ & n.a. & 1.59 & 0.78 & -0.09 \\
\hline 2. & Russia & $-6.7 \%$ & $-6.5 \%$ & 1.58 & 0.75 & -0.22 \\
\hline 3. & Mexico & $0.6 \%$ & $3.6 \%$ & 3.01 & 0.56 & -0.39 \\
\hline 4. & Croatia & $-1.0 \%$ & $-1.9 \%$ & 2.00 & 0.54 & 0.04 \\
\hline 5. & Serbia & $-4.7 \%$ & $-0.6 \%$ & 1.49 & 0.44 & 0.16 \\
\hline 6. & Greece & $-6.2 \%$ & $-7.0 \%$ & 0.91 & 0.43 & 0.02 \\
\hline 7. & Chile & $2.4 \%$ & $3.5 \%$ & 0.84 & 0.42 & 0.00 \\
\hline 8. & Hungary & $1.1 \%$ & $5.8 \%$ & 1.41 & 0.42 & 0.06 \\
\hline 9. & Czech & $1.6 \%$ & n.a. & 1.28 & 0.37 & -0.01 \\
\hline 10. & Romania & $-2.3 \%$ & $-4.9 \%$ & 1.45 & 0.36 & 0.14 \\
\hline 11. & Korea & $0.1 \%$ & n.a. & 0.79 & 0.34 & -0.05 \\
\hline 12. & Morocco & $-1.2 \%$ & $0.3 \%$ & 0.89 & 0.33 & -0.26 \\
\hline 13. & Japan & $1.5 \%$ & $2.4 \%$ & 0.89 & 0.27 & -0.06 \\
\hline 14. & Latvia & $2.1 \%$ & n.a. & 1.07 & 0.26 & 0.36 \\
\hline 15. & Italy & $-3.4 \%$ & n.a. & 1.02 & 0.25 & 0.04 \\
\hline 16. & Estonia & $5.1 \%$ & n.a. & 1.01 & 0.25 & 0.33 \\
\hline 17. & Australia & $4.0 \%$ & $5.6 \%$ & 0.65 & 0.23 & -0.12 \\
\hline 18. & Malta & $-1.4 \%$ & n.a. & 0.92 & 0.23 & 0.01 \\
\hline 19. & Slovakia & $0.2 \%$ & n.a. & 1.11 & 0.18 & 0.03 \\
\hline 20. & Israel & $6.8 \%$ & n.a. & 1.56 & 0.15 & 0.02 \\
\hline 21. & Slovenia & $-1.4 \%$ & $-0.2 \%$ & 1.45 & 0.14 & 0.00 \\
\hline 22. & Austria & $4.2 \%$ & $4.3 \%$ & 1.28 & 0.14 & 0.07 \\
\hline 23. & Lithuania & $1.4 \%$ & $2.1 \%$ & 0.99 & 0.13 & 0.22 \\
\hline 24. & Kazakhstan & $0.5 \%$ & n.a. & 1.67 & 0.13 & -0.17 \\
\hline 25. & Luxembourg & $3.7 \%$ & n.a. & 1.53 & 0.12 & 0.02 \\
\hline 26. & Malaysia & $6.2 \%$ & $7.2 \%$ & 0.85 & 0.08 & -0.37 \\
\hline 27. & Cyprus & $-0.3 \%$ & n.a. & 1.47 & 0.06 & 0.09 \\
\hline 28. & Taiwan & $4.9 \%$ & n.a. & 0.53 & 0.05 & 0.01 \\
\hline 29. & Indonesia & $-0.1 \%$ & $-1.2 \%$ & 1.05 & 0.04 & -0.08 \\
\hline 30. & Brazil & $4.4 \%$ & $1.0 \%$ & 0.69 & 0.03 & -0.24 \\
\hline 31. & Portugal & $0.1 \%$ & n.a. & 0.35 & 0.02 & -0.06 \\
\hline 32. & South Africa & $0.0 \%$ & n.a. & 0.17 & 0.02 & 0.06 \\
\hline 33. & United States & $1.7 \%$ & n.a. & 1.26 & 0.01 & -0.03 \\
\hline 34. & Switzerland & $3.5 \%$ & n.a. & 0.75 & 0.00 & 0.03 \\
\hline 35. & Germany & $2.4 \%$ & $6.9 \%$ & 1.18 & 0.00 & 0.06 \\
\hline 36. & Ireland & $-0.3 \%$ & $3.0 \%$ & 0.11 & -0.03 & 0.03 \\
\hline 37. & Singapore & $-0.1 \%$ & n.a. & 0.73 & -0.05 & -0.36 \\
\hline 38. & Canada & $5.3 \%$ & $7.1 \%$ & 1.14 & -0.06 & -0.12 \\
\hline 39. & Thailand & $1.7 \%$ & $1.7 \%$ & 0.67 & -0.08 & 0.35 \\
\hline 40. & France & $0.3 \%$ & $4.0 \%$ & 1.04 & -0.09 & 0.04 \\
\hline 41. & New Zealand & $5.6 \%$ & $6.0 \%$ & 0.39 & -0.09 & 0.09 \\
\hline 42. & $\begin{array}{c}\text { United } \\
\text { Kingdom }\end{array}$ & $2.1 \%$ & $5.2 \%$ & 1.05 & -0.09 & 0.04 \\
\hline 43. & Netherlands & $-1.2 \%$ & n.a. & 1.34 & -0.09 & 0.02 \\
\hline 44. & Belgium & $0.7 \%$ & n.a. & 0.87 & -0.20 & 0.08 \\
\hline 45. & Colombia & $4.8 \%$ & $5.2 \%$ & 0.96 & -0.22 & -0.87 \\
\hline 46. & Sweden & $5.6 \%$ & n.a. & 1.32 & -0.26 & -0.06 \\
\hline 47. & Iceland & $5.1 \%$ & $5.4 \%$ & 0.96 & -0.30 & -0.29 \\
\hline 48. & Finland & $0.2 \%$ & $0.5 \%$ & 1.60 & -0.33 & 0.06 \\
\hline 49. & Norway & $3.9 \%$ & $5.3 \%$ & 0.99 & -0.50 & -0.03 \\
\hline 50. & Denmark & $1.4 \%$ & n.a. & 0.80 & -0.73 & 0.18 \\
\hline
\end{tabular}

Note. the table reports selected data for 2010-2017, including mean inflation-adjusted returns in the national market and capital cities, and changes in mean, volatility and kurtosis of average daily temperatures. Years with fewer than 360 observations are omitted. Countries are ranked by changes in volatility in descending order. 
Results suggest several possible lines of investigation. First, changes in the volatility of daily temperatures could be correlated with levels of ; countries at the top of the list are less developed than the G7 group. Second, it appears that an increase in average temperature may be positively correlated with volatility increases. Pairwise correlation between the first and second moment of distribution reported in table 3 is 0.39 , and the statistic is significant at one percent level. However, the result does not hold for data with annual frequencies and is not observed in previous periods.

\subsection{Multivariate Tests}

We proceed to test changes in volatility in regression with means. In panel A in table 4 volatility variable attains significance at conventional levels in all models; in a univariate model, it explains 24 percent of the variance in real estate returns. The result does not appear to be spurious - betas are negative in the 1996-2007 period, although they attain significance in only two models out of six in panel C of table 4. In 1996-2007, volatility increase explained 8 percent of the variance the dependent variable.

Table 4. Regressions with means for national markets

\begin{tabular}{|c|c|c|c|c|c|c|}
\hline \multicolumn{7}{|c|}{ Panel A. OLS Regression models results for domestic markets, 2010-2017 } \\
\hline & $(1)$ & $(2)$ & (3) & (4) & $(5)$ & (6) \\
\hline \multirow[t]{2}{*}{ Change in volatility } & $-0.05 * * *$ & $-0.04 * * *$ & $-0.05 * * *$ & $-0.05 * * *$ & $-0.04 * * *$ & $-0.05 * * *$ \\
\hline & 0.01 & 0.01 & 0.01 & 0.01 & 0.01 & 0.02 \\
\hline \multirow[t]{2}{*}{ Real interest rate } & & $-0.37 * * *$ & & & & \\
\hline & & 0.17 & & & & \\
\hline \multirow[t]{2}{*}{ FX depreciation } & & $-0.39 * * *$ & & & & \\
\hline & & 0.15 & & & & \\
\hline \multirow[t]{2}{*}{ Immigration } & & & $2.21 *$ & & & \\
\hline & & & 1.18 & & & \\
\hline \multirow[t]{2}{*}{ Population increase, net } & & & & $1.23 * *$ & & \\
\hline & & & & 0.49 & & \\
\hline \multirow[t]{2}{*}{ Increase in household credits } & & & & & & 0.13 \\
\hline & & & & & & 0.15 \\
\hline \multirow[t]{2}{*}{ Increase in building permits } & & & & & $0.07 * *$ & \\
\hline & & & & & 0.03 & \\
\hline \multirow[t]{2}{*}{ Construction costs } & & & & & & -0.02 \\
\hline & & & & & & 0.02 \\
\hline \multirow[t]{2}{*}{ Growth, GDP per capita } & & & $0.57 * *$ & $0.47 * *$ & & \\
\hline & & & 0.24 & 0.23 & & \\
\hline N. of observations & 50 & 48 & 49 & 50 & 45 & 32 \\
\hline R-square & 0.24 & 0.38 & 0.35 & 0.38 & 0.34 & 0.29 \\
\hline Adjusted R-square & 0.23 & 0.34 & 0.30 & 0.34 & 0.30 & 0.21 \\
\hline \multicolumn{7}{|c|}{ Panel B. Betas and goodness-of-fit measures, 2008-2009 } \\
\hline \multirow[t]{2}{*}{ Change in volatility } & 0.02 & 0.02 & 0.01 & 0.01 & 0.02 & 0.01 \\
\hline & 0.02 & 0.02 & 0.02 & 0.02 & 0.02 & 0.02 \\
\hline R-square & 0.02 & 0.24 & 0.19 & 0.12 & 0.03 & 0.02 \\
\hline \multicolumn{7}{|c|}{ Panel C. Betas and goodness-of-fit measures, 1996-2007 } \\
\hline \multirow[t]{2}{*}{ Change in volatility } & $-0.09 *$ & $-0.11 * *$ & -0.06 & -0.06 & -0.07 & -0.04 \\
\hline & 0.05 & 0.05 & 0.04 & 0.04 & 0.05 & 0.03 \\
\hline R-square & 0.08 & 0.25 & 0.47 & 0.46 & 0.06 & 0.57 \\
\hline
\end{tabular}

Control variables suggest that results are plausible. Interest rates and domestic currency depreciation are negatively correlated with housing price inflation, whereas GDP growth, population increases and migration fuel price appreciation. Finally, the positive coefficient on building permits increase is in line with previously reported results - Hwang and Quigley (2006) report a positive coefficient on housing supply, whereas Case and Shiller (2003) argue that housing starts may measure supply restrictions. Overall, results in annual regressions suggest that volatility increases lowered real estate price increases in 2010-2018. Next, we examine whether 
results can be replicated using data with annual frequencies and in a sample of twenty-eight capital cities using regressions with means (tables 5 and 6). To make results directly replicable, capital cities subsample includes only observations for which national-level data are available.

Table 5. Regressions with annual data frequency for national markets

\begin{tabular}{|c|c|c|c|c|c|c|}
\hline \multicolumn{7}{|c|}{ Panel A. Selected output for models with annual rates, 2010-2017 } \\
\hline \multirow{3}{*}{ Change in volatility } & (1) & (2) & (3) & (4) & (5) & (6) \\
\hline & $-0.015^{* * *}$ & $-0.013^{* * *}$ & $-0.012 * * *$ & $-0.012 * * *$ & $-0.013^{* * *}$ & $-0.012 * *$ \\
\hline & 0.005 & 0.005 & 0.005 & 0.004 & 0.005 & 0.006 \\
\hline N. of observations & 329 & 313 & 323 & 328 & 288 & 401 \\
\hline R-square & 0.03 & 0.08 & 0.14 & 0.15 & 0.03 & 401 \\
\hline Adjusted R-square & 0.03 & 0.07 & 0.13 & 0.14 & 0.03 & 0.057 \\
\hline \multicolumn{7}{|c|}{ Panel B. Betas and goodness-of-fit measures, 2008-2009 } \\
\hline \multirow[t]{2}{*}{ Change in volatility } & -0.00 & 0.02 & 0.01 & 0.01 & 0.00 & -0.00 \\
\hline & 0.02 & 0.02 & 0.02 & 0.02 & 0.02 & 0.01 \\
\hline R-square & 0.00 & 0.04 & 0.27 & 0.20 & 0.00 & 0.02 \\
\hline \multicolumn{7}{|c|}{ Panel C. Betas and goodness-of-fit measures, 1996-2007 } \\
\hline \multirow[t]{2}{*}{ Change in volatility } & 0.00 & 0.00 & 0.00 & -0.00 & -0.01 & 0.00 \\
\hline & 0.02 & 0.01 & 0.01 & 0.01 & 0.02 & 0.01 \\
\hline $\mathrm{R}$-square & 0.00 & 0.15 & 0.13 & 0.08 & 0.05 & 0.17 \\
\hline
\end{tabular}

Note. The table reports selected output for models with inflation-adjusted return in national markets, annual data frequencies and Newey-West standard errors. Panels A-C report results for the 2010-2017, 2008-2009 and 1996-2007, respectively. *,**,*** indicate p-values of 10\%, 5\%, and $1 \%$, respectively.

Regressions with annual data frequencies in table 5 employ Newey-West standard errors, and control variables in both tables are suppressed - beta signs on them are consistent with output reported in table 4 for national real estate markets. In both tables - table 5 with annual frequency data and table 6 with means for capital cities betas on volatility changes take on a negative sign and are statistically significant.

Table 6. Regressions with means for capital cities

\begin{tabular}{|c|c|c|c|c|c|c|}
\hline \multicolumn{7}{|c|}{ Panel A. Selected output for regression models, 2010-2017 } \\
\hline \multirow{3}{*}{ Change in volatility } & (1) & (2) & (3) & (4) & (5) & (6) \\
\hline & $-0.07 * * *$ & $-0.05 * * *$ & $-0.04 * *$ & $-0.06 * *$ & $-0.05^{* *}$ & $-0.07 * *$ \\
\hline & 0.02 & 0.02 & 0.02 & 0.02 & 0.02 & 0.03 \\
\hline N. of observations & 28 & 28 & 28 & 28 & 23 & 18 \\
\hline R-square & 0.29 & 0.51 & 0.54 & 0.43 & 0.38 & 0.34 \\
\hline Adjusted R-square & 0.26 & 0.45 & 0.48 & 0.36 & 0.32 & 0.20 \\
\hline \multicolumn{7}{|c|}{ Panel B. Betas and goodness-of-fit measures, 2008-2009 } \\
\hline \multirow[t]{2}{*}{ Change in volatility } & 0.04 & 0.02 & 0.04 & 0.04 & 0.06 & 0.04 \\
\hline & 0.04 & 0.04 & 0.04 & 0.04 & 0.04 & 0.06 \\
\hline R-square & 0.04 & 0.14 & 0.32 & 0.21 & 0.13 & 0.11 \\
\hline \multicolumn{7}{|c|}{ Panel C. Betas and goodness-of-fit measures, 1996-2007 } \\
\hline \multirow[t]{2}{*}{ Change in volatility } & $-0.09 * *$ & $-0.09 *$ & -0.06 & -0.07 & $-0.10^{*}$ & -0.04 \\
\hline & 0.04 & 0.05 & 0.05 & 0.05 & 0.05 & 0.03 \\
\hline R-square & 0.21 & 0.26 & 0.30 & 0.31 & 0.29 & 0.74 \\
\hline
\end{tabular}

Note. The table reports OLS regression model results with variable means for each variable. The dependent variable is inflation-adjusted return in national real estate markets. Panels A-C report results for the 2010-2017, 2008-2009 and 1996-2007, respectively. *** and *** indicate a p-value of $10 \%, 5 \%$, and $1 \%$, respectively.

\section{Robustness checks}

In table 7, we confirm that earlier results are not driven by outliers. We exclude Spain and Russia - two markets with the most significant increases in the volatility of temperature in 2010-2017 - from the original sample of 50 national markets. Change in volatility variable attains significance at conventional levels in all but one model (\#6), in which only 30 out of 48 observations are used due to lack of data on the increase in household credits and construction costs, none of which attains significance. 
Further robustness checks augmented models with fixed-year effects, starting level of wealth (lagged GDP per capita $\log$ ), and sample expansion to incorporate countries for which data on returns are available for 2011-2017 rather than 2010-2017. This increases the sample size to 54 observations, adding two large markets - China and India - to the list. None of these changes affected the conclusions (results are available upon request).

Table 7. Robustness check - regressions with means for national markets

\begin{tabular}{|c|c|c|c|c|c|c|}
\hline \multicolumn{7}{|c|}{ Panel A. Regression model results in models with annual frequencies, 2010-2017 } \\
\hline \multirow{3}{*}{ Change in volatility } & (1) & (2) & (3) & (4) & $(5)$ & (6) \\
\hline & $-0.04 * * *$ & $-0.03^{* *}$ & $-0.03 * *$ & $-0.03 * *$ & $-0.02 *$ & -0.02 \\
\hline & 0.01 & 0.01 & 0.01 & 0.01 & 0.01 & 0.02 \\
\hline R-square & 0.14 & 0.30 & 0.27 & 0.30 & 0.26 & 0.22 \\
\hline \multicolumn{7}{|c|}{ Panel B. Betas and goodness-of-fit measures, 2008-2009 } \\
\hline \multirow[t]{2}{*}{ Change in volatility } & 0.03 & $0.05 * *$ & 0.01 & 0.01 & 0.03 & 0.02 \\
\hline & 0.02 & 0.02 & 0.02 & 0.02 & 0.02 & 0.02 \\
\hline R-square & 0.04 & 0.30 & 0.19 & 0.12 & 0.06 & 0.03 \\
\hline \multicolumn{7}{|c|}{ Panel C. Betas and goodness-of-fit measures, 1996-2007 } \\
\hline \multirow[t]{2}{*}{ Change in volatility } & -0.08 & $-0.10^{*}$ & -0.07 & -0.07 & -0.05 & $-0.07 * *$ \\
\hline & 0.05 & 0.05 & 0.04 & 0.04 & 0.05 & 0.03 \\
\hline R-square & 0.06 & 0.24 & 0.43 & 0.43 & 0.03 & 0.36 \\
\hline
\end{tabular}

Note. The table reports OLS regression model results with variable means for each variable in 48 national markets. Data sample excludes markets with the largest increase in volatility - Spain and Russia. Panels A-C report results for the 2010-2017, 2008-2009 and 1996-2007, respectively. *** and $* * *$ indicate a p-value of $10 \%, 5 \%$, and $1 \%$, respectively.

\section{Concluding Remarks}

Our results provide direct statistical evidence that weather changes affect asset prices. We test changes in weather conditions using higher moments of the distribution, deviations from optimal temperatures and climate risk index reported by Germanwatch to measure the impact of extreme weather events. In 2010-2017, residential real estate prices were inversely related to changes in temperature volatility, but not other tested metrics.

Interestingly, volatility changes are positively correlated with temperature increases in this period. Therefore, volatility may capture the impact of changes in other weather-related characteristics. This is one potential area of future research.

Given the size of the real estate market and its allocation in the households' aggregate balance sheet (Note 2), The results of this paper can be of interest to both retail investors and investment advisors. Also, they are relevant for policymakers due to the climate's impact on social dynamics and climate adaptation policies. Hsiang, Burke, and Miguel (2013) summarize sixty studies from different fields and document that one standard deviation change in climate variables is associated with a probability change of intergroup conflict and interpersonal violence by fourteen percent and four percent, respectively. Increase in intergroup tensions provides another channel through which weather changes could affect real estate prices.

One of the shortcomings of this study is that it uses a straightforward metric to gauge the influence of weather changes, whereas the effects are likely non-linear (Albuoy et al., 2016; Zivin \& Neidell, 2012). Further, climate change impact may not be measured directly and immediately - among other consequences; higher temperatures lead to species extinction and ecosystem dysfunction. It is, therefore, possible that in other periods weather changes may be captured through different moments of the distribution. This study represents the first step to fill this knowledge void.

\section{References}

Adams, Z., \& Füss, R. (2010), Macroeconomic determinants of international housing markets. Journal of Housing Economics, 19(1), 38-50. https://doi.org/10.1016/j.jhe.2009.10.005

Albouy, D., Graf, W., Kellogg, R., \& Wolff, H. (2016). Climate amenities, climate change, and American quality of life. Journal of the Association of Environmental and Resource Economists, 3(1), 205-246. https://doi.org/10.1086/684573

Ballesteros-Perez, P., Smith, S. T., Lloyd-Papworth, J. G., \& Cooke, P. (2018). Incorporating the effect of weather in construction scheduling and management with sine wave curves: Application in the United Kingdom. Construction Management and Economics, 36(12), 666-682. 
https://doi.org/10.1080/01446193.2018.1478109

Barro, R. J. (2006). Rare disasters and asset markets in the twentieth century. The Quarterly Journal of Economics, 121(3), 823-866. https://doi.org/10.1162/qjec.121.3.823

Bunten, D., \& Kahn, M. E. (2014). The impact of emerging climate risks on urban real estate price dynamics. National Bureau of Economic Research, Working Paper 20018. https://doi.org/10.3386/w20018

Butsic, V., Hanak, E., \& Valletta, R. G. (2011). Climate change and housing prices: Hedonic estimates for ski resorts in Western North America. Land Economics, 87(1), 75-91. https://doi.org/10.3368/le.87.1.75

Campbell, S. D., Davis, M. A., Gallin, J., \& Martin, R. F. (2009). What moves housing markets: A variance decomposition of the rent-price ratio. Journal of Urban Economics, 66(2), 90-102. https://doi.org/10.1016/j.jue.2009.06.002

Case, K. E., \& Shiller, R. J. (1989). The efficiency of the market for single-family homes. American Economic Review, 79(1), 125-137. https://doi.org/10.3386/w2506

Case, K. E., \& Shiller, R. J. (2003). Is there a bubble in the housing market? Brookings Paper on Economic Activity, 34(2), 299-362. https://doi.org/10.1353/eca.2004.0004

Deryugina, T., \& Hsiang, S. H. (2014). Does the environment still matter? Daily temperatures and income in the United States. National Bureau of Economic Research, Working Paper 20750. https://doi.org/10.3386/w20750

Dlugolecki, A. (2008). Climate change and the insurance sector. The Geneva Papers on Risk and Insurance Issues and Practice, 33(1), 71-90. https://doi.org/10.1057/palgrave.gpp.2510152

Giglio, S., Maggiori, M., Stroebel J., \& Weber, A. (2015). Climate change and long-run discount rates: Evidence from real estate. National Bureau of Economic Research, Working Paper 21767. https://doi.org/10.3386/w21767

Girouard, N., Kennedy, M., van den Noord, P., \& Andre, C. (2006). Recent house price developments: the role of fundamentals. OECD Economics Department Working Papers, 475.

Hanak, E., Butsik, V., \& Valetta, R. G. (2011). Climate change and housing prices: Hedonic estimates for ski resorts in Western North America. Land Economics, 87(1), 75-91. https://doi.org/10.3368/le.87.1.75

Hirshleifer, D., \& Shumway, T. (2003). Good day sunshine: Stock returns and the weather. The Journal of Finance, 58(3), 1009-1032. https://doi.org/10.1111/1540-6261.00556

Ho, D. K. H., Addae-Dapaah, K., \& Glascock, J. L. (2015). International direct real estate risk premiums in a multi-factor estimation model. Journal of Real Estate Finance and Economics, 51(1), 52-85. https://doi.org/10.1007/s11146-014-9474-z

Hsiang, S. M., Burke, M., \& Miguel, E. (2013). Quantifying the influence of climate on human conflict. Science, 341(6151). https://doi.org/10.1126/science.1235367

Hwang, M., \& Quigley, J.M. (2006). Economic fundamentals in local housing markets: Evidence from US metropolitan regions. Journal of Regional Science, 46(3), 425-453. https://doi.org/10.1111/j.1467-9787.2006.00480.x

Intergovernmental Panel on Climate Change (IPCC). (2014). Climate change 2014: synthesis report. Contribution of working groups I, II and III to the fifth assessment report of the Intergovernmental Panel on Climate Change [Core Writing Team, Pachauri, P. K., \& Meyer, L. A. (Eds.)]. IPCC, Geneva, Switzerland. https://doi.org/10.1017/CBO9781107415416

Kahn, M. E. (2009). Urban growth and climate change. The Annual Review of Economics, 1(1), 333-349. https://doi.org/10.1146/annurev.resource.050708.144249

Kishor, K. N., \& Marfatia, H. A. (2017). The dynamic relationship between housing prices and the macroeconomy: Evidence from OECD countries. Journal of Real Estate Finance and Economics, 54(2), 237-268. https://doi.org/10.1007/s11146-015-9546-8

Krainer, J., \& Wei, C. (2004). House prices and fundamental value. FRBSF Economic Letter.

Lai, R.N., \& Van Order, R. (2017). U.S. House Prices over the last 30 years: bubbles, regime shifts and market (in)efficiency. Real Estate Economics, 45(2), 259-300. https://doi.org/10.1111/1540-6229.12127

Lesnikowski, A., Ford, J. D., Blesbroek, R., \& Berrang-Ford, L. (2019). A policy mixes approach to 
conceptualizing and measuring climate change adaptation policy. Climatic Change, (issue not assigned). https://doi.org/10.1007/s10584-019-02533-3

Li, R. Y. M. (2009). The impact of climate change on residential transactions in Hong Kong. The Built \& Human Environment Review, 2(1), 11-22. https://doi.org/10.2139/ssrn.1429727

Li, R. Y. M., Cheng, K. Y., \& Shoaib, M. (2018). Walled buildings, sustainability, and housing prices: an artificial neural network approach. Sustainability, 10,1-17. https://doi.org/10.3390/su10041298

Linneman, P. (1986). An empirical test of the efficiency of the housing market. Journal of Urban Economics, 20(2), 140-154. https://doi.org/10.1016/0094-1190(86)90003-3

Mechler, R., Bouwer, L., Schinko, T., Surminski, S. \& Linnerooth-Bayer, J. (Eds.) (2019). The road traveled and pathways forward: A review of Loss and Damage from Climate Change: Concepts, Methods and Policy Options. https://doi.org/10.1007/978-3-319-72026-5

Nordhaus, W. D. (2011). The economics of tail events with an application to climate change. Review of Environmental Economics and Policy, 5(2), 240-257. https://doi.org/10.1093/reep/rer004

Patt, A. G., Tadross, M., Nussbaumer, P., Asante, K., Metzger, M., Rafael, J., Goujon, A., \& Brundrit, G. (2010). Estimating least-developed countries' vulnerability to climate-related extreme events over the next 50 years. Proceedings of the National Academy of Sciences of the United States of America, 107(4), 1333-1337. https://doi.org/10.1073/pnas.0910253107

Roback, J. (1982) Wages, Rents, and the Quality of Life. Journal of Political Economy, 90(6), 1257-1278. https://doi.org/10.1086/261120

Somanathan, E., Somanathan, R., Sudarshan, A., \& Tewari, M. (2015). The impact of temperature on productivity and labor supply: evidence from Indian manufacturing. Indian Statistical Institute, Delhi Economics and Planning Unit, Discussion paper 14-10.

Weitzman, M. L. (2011). Fat-tailed uncertainty in the economics of catastrophic climate change. Review of Environmental Economics and Policy, 5(2), 275-292. https://doi.org/10.1093/reep/rer006

Zander, K., Botzen, W. J. W., Oppermann, E., Kjellstrom, T., \& Garnett, S. T. (2015). Heat stress causes substantial labour productivity loss in Australia. Nature Climate Change, 5(7), 647-652. https://doi.org/10.1038/nclimate2623

Zivin, G. J., \& Neidell, M. (2014). Temperature and the allocation of time: implications for climate change. Journal of Labor Economics, 32(1), 1-26. https://doi.org/10.1086/671766

\section{Notes}

Note 1. https://home.kpmg.com/xx/en/home/services/tax/tax-tools-and-resources/tax-rates-online/individualincome-tax-rates-table.html (accessed November 1, 2019).

Note 2. see U.S. data provided by the Federal Reserve at https://fred.stlouisfed.org/series/OEHRENWBSHNO and www.federalreserve.gov/releases/z1/dataviz/z1/balance_sheet/chart/, accessed on Dec 30, 2018.

\section{Appendix A. Sources of data for daily temperatures, interest rates and building permits}

\begin{tabular}{|c|c|c|c|c|}
\hline & GIS TEMP station & Building permits series & Construction costs & Interest rate series \\
\hline Australia & East Sale Airport & AUYODI15G & AUWOPVCOF & TRAU10Y \\
\hline Austria & Wien & OEESK1HFE & OEYOP003F & TROE10T \\
\hline Belgium & Uccle & BGESK1HFG & BGESPPUZR & TRBG10T \\
\hline Brazil & Sao Paolo Aeroport & n.a. & BRCPCIM.F & $\begin{array}{l}\text { BRSELIC prior to 2006; } \\
\text { TRBR10T starting } 2006\end{array}$ \\
\hline Canada & L'Assomption, QC & CNYODI15Q & CNYOP003F & TRCN10T \\
\hline Chile & Arturo Menino Benitzz International & CLYOD008Q & n.a. & TRCL10T \\
\hline Colombia & Bogota Eldorado & CBYODI15G & CBHOUSE\%R & $\begin{array}{l}\text { CBBCBPR before 2002; } \\
\text { TRCO10T starting } 2002\end{array}$ \\
\hline Croatia & Zagreb Gric & CTESUM8SF & CTAPWC4. & $\begin{array}{l}\text { CTPRATE. before 2008; } \\
\text { TRHR10T starting } 2008\end{array}$ \\
\hline
\end{tabular}




\begin{tabular}{|c|c|c|c|c|}
\hline Cyprus & General Bernardo O Higgins & CPESUM8SH & CPCONSTRF & CPY61... \\
\hline Czech Republic & Praha Libus & CZYODI15H & CZESXY7DR & $\begin{array}{l}\text { CZBCBPR prior to 2000; } \\
\text { TRCZ10T starting } 2000\end{array}$ \\
\hline Denmark & Koebenhavn Landbohojskolen 1 & DKYODI15Q & DKESXY7DR & TRDK10T \\
\hline Estonia & Tallinn & EOYODI15P & DKESXY7DR & $\begin{array}{l}\text { EOIBK1Y in 1999-2011; } \\
\text { EOQIR076R otherwise }\end{array}$ \\
\hline Finland & Helsinki Kaisaniemi AWS & FNYODI15H & FNYOP005F & TRFN10T \\
\hline France & Paris Le Bourget & FRYODI15G & FRESXY7DR & TRFR10T \\
\hline Germany & Berlin Tegel & BDYODI15G & BDYOP003F & TRBD10T \\
\hline Greece & Larissa & GRYODI15H & GRCCIRESF & TRGR10T \\
\hline Hungary & Debrecen & HNYODI15G & HNESXY7DR & $\begin{array}{l}\text { HNBBASE prior to } 1999 \text {; } \\
\text { TRHN10T starting } 1999\end{array}$ \\
\hline Iceland & Reykjavik & ICHOUSCN & ICYOP003F & $\begin{array}{l}\text { ICBCBPR prior to } 2003 \text {; } \\
\text { TRIS10T starting } 2003\end{array}$ \\
\hline Indonesia & Zamboanga & n.a. & n.a. & $\begin{array}{l}\text { IDYIR076R in } 1998-2002 ; \\
\text { TRID10T starting } 2003\end{array}$ \\
\hline Ireland & Dublin Phoenix Park & IRYODI15Q & IRESTICKR & TRIE10T \\
\hline Israel & Elat & ISYODI15H & ISBLDPRCF & ISMIR080R \\
\hline Italy & Roma Ciampino & ITESUM8SF & ITYOP003F & TRIT10T \\
\hline Japan & Tokyo & JPYWSI41Q & JPCSBNDLF & TRJP10T \\
\hline Kazakhstan & Almaty & KZCONRESA & KZCSTPRCF & KZGBOND. \\
\hline Korea, South & Seoul City & KOYOD008Q & KOPPSMCTFA & $\begin{array}{l}\text { KOQIR063R prior to 2000; } \\
\text { KOOIR080R starting } 2000\end{array}$ \\
\hline Latvia & Daugavpils & LVYODI15H & LVESXY7DR & $\begin{array}{l}\text { LVYIR076R in 1998-1999; } \\
\text { LVGBD5Y starting } 2000\end{array}$ \\
\hline Lithuania & Vilnius & LNQODI15H & LNESXY7DR & $\begin{array}{l}\text { LNRPAON prior to } 2003 \text {; } \\
\text { LNGBOND starting } 2003\end{array}$ \\
\hline Luxembourg & Luxembourg Airport & LXYODI15G & LXESXY7DR & LXBENCH \\
\hline Malaysia & Kuala Lumpur International & n.a. & n.a. & MYGBOND. \\
\hline Malta & Luqa & MAESUM8SF & MAESXY7DR & $\begin{array}{l}\text { MAY61... prior to } 2007 \text {; } \\
\text { MAGBD10 starting } 2007\end{array}$ \\
\hline Mexico & Cuernavaca & MXGD8FCRA & MXPPDCONFAC & $\begin{array}{l}\text { MXYIR066R prior to 2002; } \\
\text { MXYIR080R starting } 2002\end{array}$ \\
\hline Morocco & Tangier City & n.a. & n.a. & $\begin{array}{l}\text { MCGBOND.; } \\
\text { when not available, MCPRATE }\end{array}$ \\
\hline Netherlands & Den Helder 1 & NLESK1HFE & NLESXY7DR & NLGBOND. \\
\hline New Zealand & Invercargill Airpor & NZYODI15G & NZPIBUCOF & NZYIR080R \\
\hline Norway & Oslo Blindern & NWYODI15G & NWESTICKR & NWGBOND. \\
\hline Portugal & Lisboa Geofisica & PTYODI15H & PTYOP005F & TRPT10T \\
\hline Romania & Bucuresti Baneasa & RMESUM8SH & RMES3W6JQ & TRRO10T \\
\hline Russia & Moscow & RSCONBRN & RSCRPTOT & $\begin{array}{l}\text { TRRS6MT prior to } 1999 ; \\
\text { RSQIR080R starting } 1999\end{array}$ \\
\hline Serbia & Belgrade Observatory & n.a. & n.a. & SBBCBPR \\
\hline Singapore & Singapore Changi International & SPPRSUPIP & n.a. & TRSG10T \\
\hline Slovakia & Hurbanovo & SXOAJ32XA & SXESXY7DR & SXOIR080R \\
\hline Slovenia & Ljubljana Bezigrad & SJYODI15P & SJESXY7DR & $\begin{array}{l}\text { SJESSFUB after 2002; } \\
\text { SJTBL3M in 1998-2002 }\end{array}$ \\
\hline South Africa & Upington Agr. & SAYODI15O & SAAVMCONA & TRSA10T \\
\hline Spain & Madrid Barajas & ESYODI15H & ESESXY7DR & TRES10T \\
\hline Sweden & Stockholm & SDYODI15H & SDESXY7DR & TRSD10T \\
\hline Switzerland & Zuerich Fluntern & SWAOD008Q & SWESXY7DR & TRSW10T \\
\hline Taiwan & Ishigaki & TWBPNUHHP & TWCONCSTF & TRTW10T \\
\hline Thailand & Chanthaburi & THCONRESP & THEAAVCOA & THGBOND. \\
\hline United Kingdom & Heathrow & UKAOD008Q & UKESXY7DR & TRUK10T \\
\hline United States & La Guardia Airport & USBCIPEHO & USPMTCFCE & TRUS10T \\
\hline
\end{tabular}

\section{Copyrights}

Copyright for this article is retained by the author(s), with first publication rights granted to the journal.

This is an open-access article distributed under the terms and conditions of the Creative Commons Attribution license (http://creativecommons.org/licenses/by/4.0/). 